\title{
University challenges plagiarism judgement
}

Tokyo. The University of Hong Kong, rejecting the judgement of Hong Kong's High Court and Court of Appeal, has cleared a faculty member of charges of plagiarism and infringing copyright in a questionnaire used for an epidemiological study of lung cancer. But the impartiality of the university's investigation has been questioned by the researcher who brought the initial charges.

In a precedent-setting court case, the appeal court confirmed in August 1993 a high-court verdict reached the previous year that Lam Tai Hing, a reader in the university's department of community medicine, made unauthorized use of a questionnaire devised by a lecturer in the department (see Nature 366, 715; 1993). But a subsequent internal inquiry by the university cleared Lam of the charges.

The case started in 1986 when Linda $\mathrm{Koo}$, a lecturer in the department, accused Lam of copying parts of a questionnaire that she had devised with John Ho Hung Chui, honorary professor of radiation oncology at the university, to study the incidence of lung cancer in non-smoking women.

Her claims set an unusual precedent, as several leading epidemiologists argue that such questionnaires are usually freely circulated among researchers and are not considered subject to copyright. But Koo alleges that she was being harassed by Lam and the then head of the department, J. W. I. Kleevens, and that this was a driving force behind her decision to go to court.

The university's inquiry was carried out by a committee of two pro-vice-chancellors and four members of the senate. The committee met in private 14 times between October 1993 and November 1994 and heard evidence in Lam's defence from Lam, his lawyer and several witnesses.

It also examined some of the extensive court records and received written opinions on the similarity of Koo and Lam's questionnaires from 26 eminent epidemiologists from Britain, the United States, Singapore and Australia. Neither Koo nor Ho, their lawyers, nor witnesses for the plaintiffs, participated in the hearings.

In a report released on 20 January, the committee, saying that it required more substantial proof of guilt than the high court, dismissed all charges against Lam. It claims that new evidence shows that an assistant of Koo's may have given the questionnaire to Lam's assistant, and concludes there is no evidence that Lam stole it, as Koo alleges.

In contrast to the court ruling, the committee says that Lam's questionnaire was not copied from Koo and Ho's. It also quotes a "clear majority view " from epidemiologists and other scientists that in the 1980s "there was no copyright or confidentiality in questionnaires, and the practice was free exchange and use of such material".
But Koo challenges the impartiality of these experts. She points out that their comments were solicited by the head of Lam's department, A. J. Hedley, and that, in the words of the committee's report, Hedley's letter to them was "highly tendentious and was (in lawyer's language) 'leading'",

For example, Hedley's letter said that Koo's attitude was affected by her failure to gain promotion in 1984, questioned the basis of the judge's decision, mentioned a widespread sense of grave miscarriage of justice and also spoke strongly of the need for free circulation of questionnaires. Nevertheless, the committee said it placed great weight on the views of these 26 experts as they are "senior and distinguished scientists, who can be expected to have an independent mind".

Richard Peto, professor of medical statistics and epidemiology at the University of Oxford in Britain, who acted as expert defence witness in the high court trial and also presented evidence to the internal inquiry, says "justice has been done at last". In contrast, Koo says the inquiry was a "kangaroo court" and "whitewash job" to clear Lam's name and the reputation of the university. She says the committee report shows "total disrespect for the court system".

The committee criticizes Koo and Ho for not agreeing to give oral evidence and denying the committee access to relevant material. But Koo wrote to the committee's secretary suggesting dates on which she and Ho could appear before the committee, and she offered to bring all 75 box files they had on the case to the hearing. The committee replied that it "did not initially foresee the need" for them to bring the box files. It also said that, while Lam would be represented by his lawyer, who could ask questions of them and other witnesses, the lawyer for $\mathrm{Koo}$ and Ho could attend only as an "observer". On advice from their lawyer, the two declined to participate.

The university says it considers the whole matter closed. But Koo says that she is now seeking advice from her lawyer on the possibilities of legal action against the university.

\section{Darwin's islands under threat}

London. Scientists are being asked to write letters of protest to the President of Ecuador about threats from sea-cucumber fishermen to the wildlife of the Galapagos Archipelago, the islands that gave Darwin the inspiration for his theory of natural evolution.

According to conservationists, the overfishing of the sea cucumber, Isostichopus fuscus, an important link near the base of the food chain, and an influx of people to the islands to exploit the lucrative trade, is threatening the wildlife of the islands. This in turn could destroy the tourist industry on which many of the 12,000 islanders depend.

Sea cucumbers are marine invertebrates that lie on the bottom of the sea feeding on detritus and plankton. The eight-inch-long rusty brown creatures are sought after in China and South-East Asia for their supposed medicinal properties.

Two months after the opening of a flsherles in the islands last October, fishermen were reported to have taken more than seven million sea cucumbers, despite a quota of 500,000 in a three-month season set by the Ecuadorian government. Snails, sea horses, sea urchins and black coral are also reported to have been taken.

The Ecuadorian authorities closed the fisheries in December, sparking violent protests last month from fishermen and dealers. According to Macarena Green, a scientist on the islands, protesters blockaded the
Charles Darwin Research Station and the headquarters of the national parks service. They took hostages and threatened to kill the giant tortoises at the research station.

In an attempt to pacify the protesters, a government official granted them an extra $\mathbf{3 0}$ days of fishing. But this was overturned almost immediately and replaced with a

\section{IMAGE UNAVAILABLE FOR COPYRIGHT REASONS}

nine-month ban after a meeting between the minister of fisheries, fishermen and conservationists. The ban reflected the efforts of scientists working with local environmental groups, tour operators, travel agents and the association of ecotourism to persuade the minister that the activities of the fishermen pose a threat to the islands.

In a message that has been broadcast on the Internet, Green urges scientists to bring international pressure on the Ecuadorian government to close the fisheries permanently.
Maggie Verrall 